\title{
Pharmacogenomics in type 2 diabetes management: towards personalized medicine
}

\author{
Cheng $\mathrm{Hu}$ \\ From 2012 Sino-American Symposium on Clinical and Translational Medicine (SAS-CTM) \\ Shanghai, China. 27-29 June 2012
}

There is inter-individual variability in the responses to anti-diabetic treatments, partly due to genetic factors involved in drug absorption, distribution, metabolism and target. The identification of genetic markers related to drug reaction can help physicians with the decisions of drug selection, dose titration, treatment duration, and avoidance of advert drug reactions. We focused on the effects of susceptibility genes for T2D on anti-diabetic drugs' efficacy. With respect to repaglinide, genetic variants at multiple loci such as CYP2C8, SLCO1B1, KCNJ11, TCF7L2 and SLC30A8, affect either its pharmacokinetics or pharmacodynamics. We also made some efforts on pharmacogenetic studies of repaglinide efficacy. We recruited a total of 104 Chinese patients with type 2 diabetes and with no history of prior antidiabetic medications, to whom subsequent repaglinide monotherapy with a 48-week follow-up was applied. Based on studies on this cohort, genetic variations at KCNJ11, ABCC8, NOS1AP and $K C N Q 1$ were found to be associated with repaglinide efficacy. Moreover, we also focused on investigations into possible genetic factors for rosiglitazone efficacy, and have already suggested effects of $A B C A 1$ and $S L C 30 A 8$ variants on the response to rosiglitazone treatment. In spite of all these advances in the field of pharmacogenetics of type 2 diabetes, the pace of clinical application of these findings is rather slow. Consequently, more researches especially randomized clinical trials into the practical utility should be conducted.

Published: 17 October 2012

Correspondence: alfredhc@sjtu.edu.cn

Shanghai Diabetes Institute, Department of Endocrinology and Metabolism, Shanghai Clinical Center for Diabetes, Shanghai Key Laboratory for Diabetes, Shanghai Jiao Tong University Affiliated Sixth People's Hospital, Shanghai, China

\section{() Biomed Central}

(c) 2012 Hu; licensee BioMed Central Ltd. This is an Open Access article distributed under the terms of the Creative Commons Attribution License (http://creativecommons.org/licenses/by/2.0), which permits unrestricted use, distribution, and reproduction in any medium, provided the original work is properly cited.
doi:10.1186/1479-5876-10-S2-A19

Cite this article as: $\mathrm{Hu}$ : Pharmacogenomics in type 2 diabetes

management: towards personalized medicine. Journal of Translational Medicine 2012 10(Suppl 2):A19.

Submit your next manuscript to BioMed Central and take full advantage of:

- Convenient online submission

- Thorough peer review

- No space constraints or color figure charges

- Immediate publication on acceptance

- Inclusion in PubMed, CAS, Scopus and Google Scholar

- Research which is freely available for redistribution 